\title{
The use of mathematical models for modelling sulphur dioxide sorption on materials produced from fly ashes
}

\author{
Natalia Czuma ${ }^{1}$, \\ Katarzyna Zarębska ${ }^{1}$, \\ Pawel Baran ${ }^{1}$, Piotr Gauden ${ }^{2}$ \\ ${ }^{1}$ AGH University of Science and Technology, \\ Al. Mickiewicza 30, 30-05 Cracow, Poland \\ Email:nczuma@agh.edu.pl \\ ${ }^{2}$ Nicolaus Copernicus University in Toruń, \\ Gagarin Street 7, 87-100 Toruń, Poland
}

\begin{abstract}
Fly ash-derived zeolites may become an attractive alternative for natural zeolites as well as for zeolites produced out of pure chemicals. A growing awareness of the need to protect the environment is an incentive for the use of waste materials as raw materials for production of microporous, multi-application materials - zeolites. Additionally, environmentally friendly actions undertaken in order to reduce air pollution intensify needs to search for new options for capturing hazardous air pollutants out of flue gases. Zeolites can be used as air pollutants sorbents. In this work there are presented results of sulphur dioxide, one of flue gases components, sorption experiments. The adsorbent used was zeolite synthesized form fly ash from a selected Polish power plant. For the purpose of investigation there were chosen fly ash zeolite samples synthesised with the use of different methods. Parameters were selected in such a way that one type of zeolite material was received. For the purpose of description of received results the mathematical model was used. As a result of experiments carried out it was found that the synthesized materials may be used as sulphur dioxide sorbent. It was found that the sorption capacity is highly connected with the zeolite synthesis method. Despite the fact that the same type of zeolite was received, samples presented differentiated values for capture, due to different conversion factors of fly ash into zeolite materials.
\end{abstract}

Keywords: fly ash, zeolite, sorption, modelling

\section{INTRODUCTION}

Taking into account still increasing restrictions connected with environmental pollutants, there is a need to search for new ways of use of waste materials as well as their effective uses [1-2]. The use of fly ashes received as a by-product of coal burning as a substrate for synthesis of ze- olites enables both: the usage of waste material and the production of materials of differentiated and high application potential - zeolites. Among the possible application of synthetic zeolites, there can be given: chemical industry, microelectronic, optical industry, building industry, agriculture and environmental protection [3]. Due to capability of capturing gases or vapours, 
zeolites may be used as air pacificators. One of possibilities of fly ash zeolite usage is sulphur dioxide sorption. In Fig. 1 there is presented correlation between the structure (what is mainly important is the size of the channel of zeolites) and its sorption properties.

In the present study there is analysed the behaviour of zeolite $\mathrm{X}$ received as a result of two different synthesis methods. The synthesis methods were selected in such a way that zeolite X was received. The sorption tests were performed three times with the use of the same sample for preliminary regeneration tests. For the description of the gas-solid phase adsorption data obtained, there were used to well-known adsorption models: Freudlich and Langmuir isotherm.

\section{RAW MATERIAL FOR SYNTHESIS}

For the purpose of the experiments there was selected fly ash form a Polish power plant burning hard coal in a pulverised boiler. The macro- and micro-scale photographs are presented in Fig. 2.

In Fig. 2a, the micro-scale picture presents fly ash. It is visible that the material is in a form of fine powder.

Figure $2 \mathrm{~b}$ presents a microphotograph performed using SEM-EDS analysis which was performed with the use of FEI QUANTA 250200 FEG. The figure shows the predominance of aluminosilicate glass particles present in fly ash.

In Fig. 3 there is presented the XRD diffraction pattern of examined fly ash, performed with

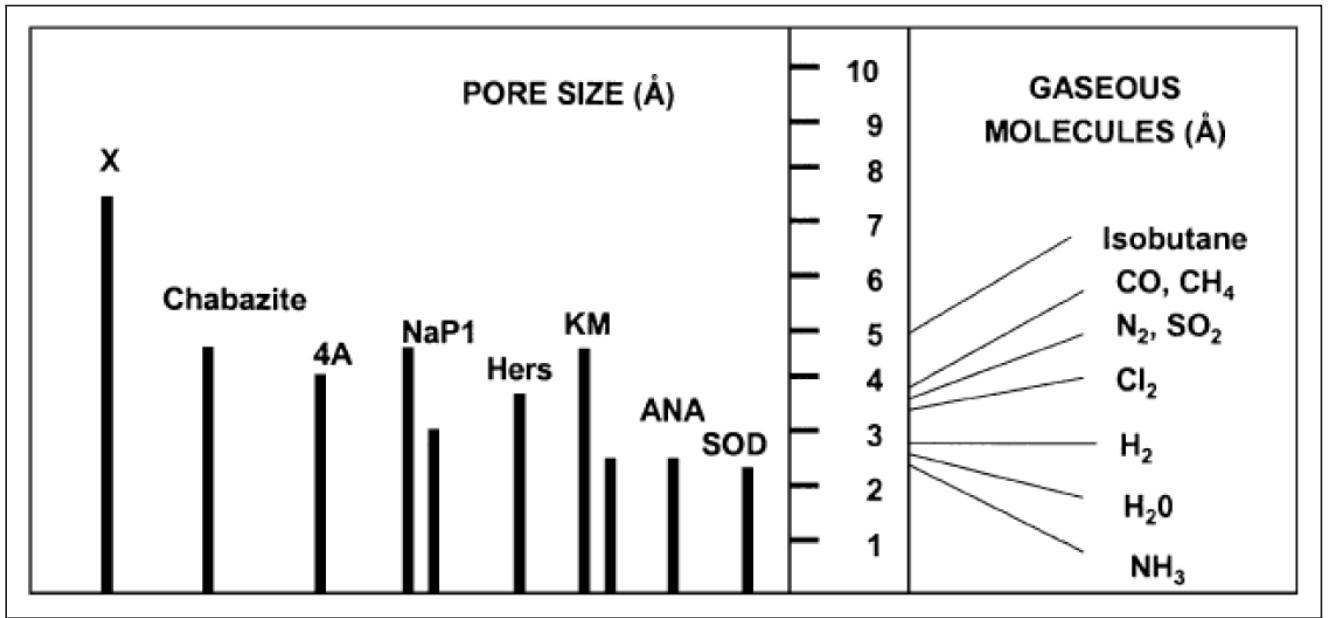

Fig. 1. Zeolite use possibilities for gases sorption [4]

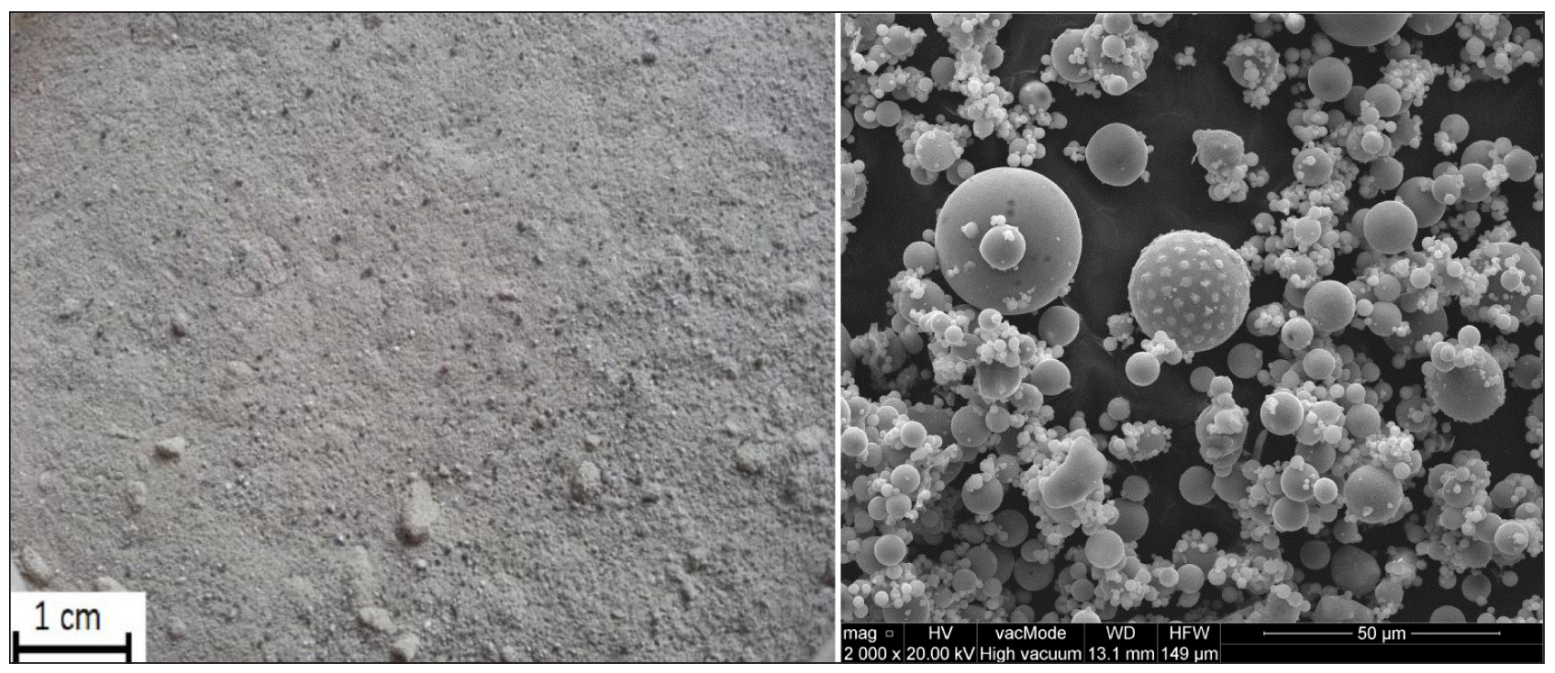

Fig. 2. Macro-scale picture of fly ash (a) and microphotograph of fly ash (b) 


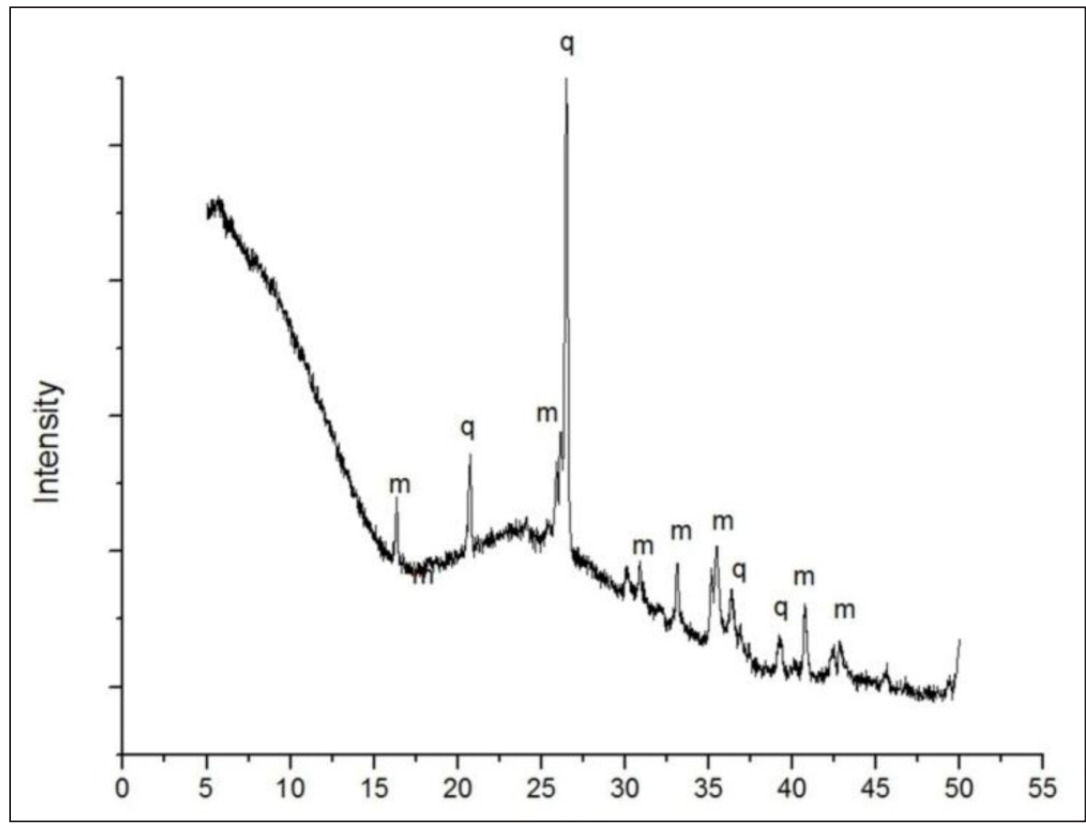

Fig. 3. Fly ash diffractogram (q-quartz, m-mullite)

the use of powder X-ray diffraction methodology, Philips X'pert APD diffractometer.

The analysis of this figure gives information of the presence of quartz and mullite as predominant cristalline phases. Additionally, a halo in range $15-35^{\circ} 2 \theta$ is observed, which corresponds to amorphous phase presence.

The oxide composition of fly ash, presented in Table 1, was investigated with the use of the X-ray fluorescence method, Epsilon 3, PANalytical spectrometer.

The oxide composition provides information of a high share of $\mathrm{Si}$ and $\mathrm{Al}$ sources in fly ash. This

Table 1. Oxide composition of fly ash substrate (major components)

\begin{tabular}{cc}
\hline Compound & Amount, \% \\
\hline $\mathrm{SiO}_{2}$ & 38.45 \\
\hline $\mathrm{Al}_{2} \mathrm{O}_{3}$ & 15.71 \\
\hline $\mathrm{Fe}_{2} \mathrm{O}_{3}$ & 10.09 \\
\hline $\mathrm{CaO}$ & 3.58 \\
\hline $\mathrm{K}_{2} \mathrm{O}$ & 2.77 \\
\hline $\mathrm{Na}_{2} \mathrm{O}$ & 2.3 \\
\hline $\mathrm{MgO}$ & 1.77 \\
\hline $\mathrm{SO}_{3}$ & 1.04 \\
\hline $\mathrm{TiO}_{2}$ & 1 \\
\hline
\end{tabular}

information allows to suspect that the raw material might be used as a substrate for fly ash zeolite synthesis.

\section{EXPERIMENTAL METHODOLOGY}

Fly ash zeolites synthesis

Both methods used for the synthesis of fly ash zeolites were selected in a way allowing for the formation of the same type of zeolite in the sample-zeolite type X [5-7].

\section{Fusion method for fly ash zeolite synthesis}

The synthesis of zeolite X by the fusion method together with hydrothermal aging of solutions was done. The fusion process was performed in the temperature of $700^{\circ} \mathrm{C}$, the used fly ash-to-sodium hydroxide ratio was 0.8 . The time of solution aging in the evaluated temperature after the fusion process was 6 hours. Received material was washed to $\mathrm{pH} \sim 10$ and dried. Received material was examined with the use of XRD and marked with symbol F.

\section{Hydrothermal method for fly ash zeolite synthesis}

The synthesis of zeolite $\mathrm{X}$ by the hydrothermal method was conducted in a temperature around $105^{\circ} \mathrm{C}$, in alkaline aqueous solution $(\mathrm{NaOH})$ with 
the addition of $\mathrm{NaCl}$ salt. The ratio of fly ash to sodium hydroxide and to sodium chloride used was $2: 4: 1$, accordingly. The time range for synthesis was 24 hours. Received material was washed to $\mathrm{pH} \sim 10$ and dried. Received material was examined with the use of XRD and marked with symbol $\mathrm{H}$.

\section{Sulphur dioxide sorption procedure}

Sulphur dioxide sorption experiments were performed with the use of Sartorius sorption microbalance. The scheme of installation was presented in Fig. 4.

The sorption temperature was $25^{\circ} \mathrm{C}$. The samples were additionally dried before the measurement, and degasified in the apparatus. The sorption experiment was performed in three following cycles (marked with symbol I for the first cycle, II for the second cycle, III for the third cycle) on the same sample to check if the desorption process is possible. The desorption was performed by lowering the pressure. Only sorption data will be presented in the results.

\section{EXPERIMENTAL RESULTS}

\section{Synthesis results}

\section{Fusion fly ash zeolite synthesis results}

As a result of fusion synthesis there was received fine powder analysed with the use of XRD. The diffraction pattern presented in Fig. 5 proves that in the sample synthesised with the use of the fusion method there was present zeolite type X.

\section{Hydrothermal method fly ash zeolite synthesis}

In case of hydrothermal synthesis the zeolite type $\mathrm{X}$ was received. The diffraction patter of the synthesized sample is presented in Fig. 5. In case of fly ash zeolites the conversion rate of fly ash into zeolite in most cases is not full. This fact results in the fact that despite zeolites present in the sample there are also present the remains of non-reacted fly ash. In case of $\mathrm{H}$ sample, there are clearly visible remains of quartz $(\mathrm{Q})$ and mullite $(\mathrm{M})$ in the sample.

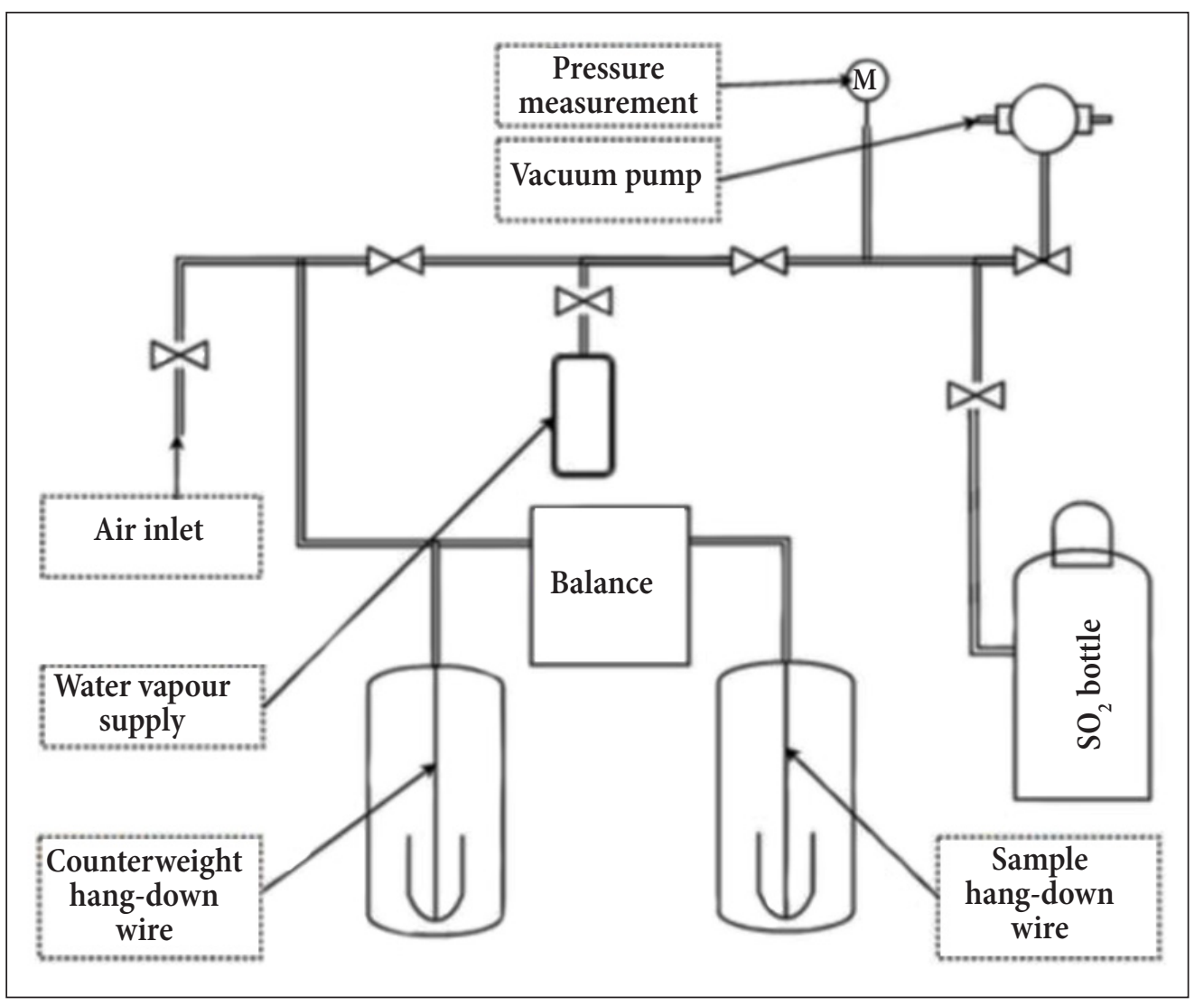

Fig. 4. Scheme for $\mathrm{SO}_{2}$ sorption experiments 


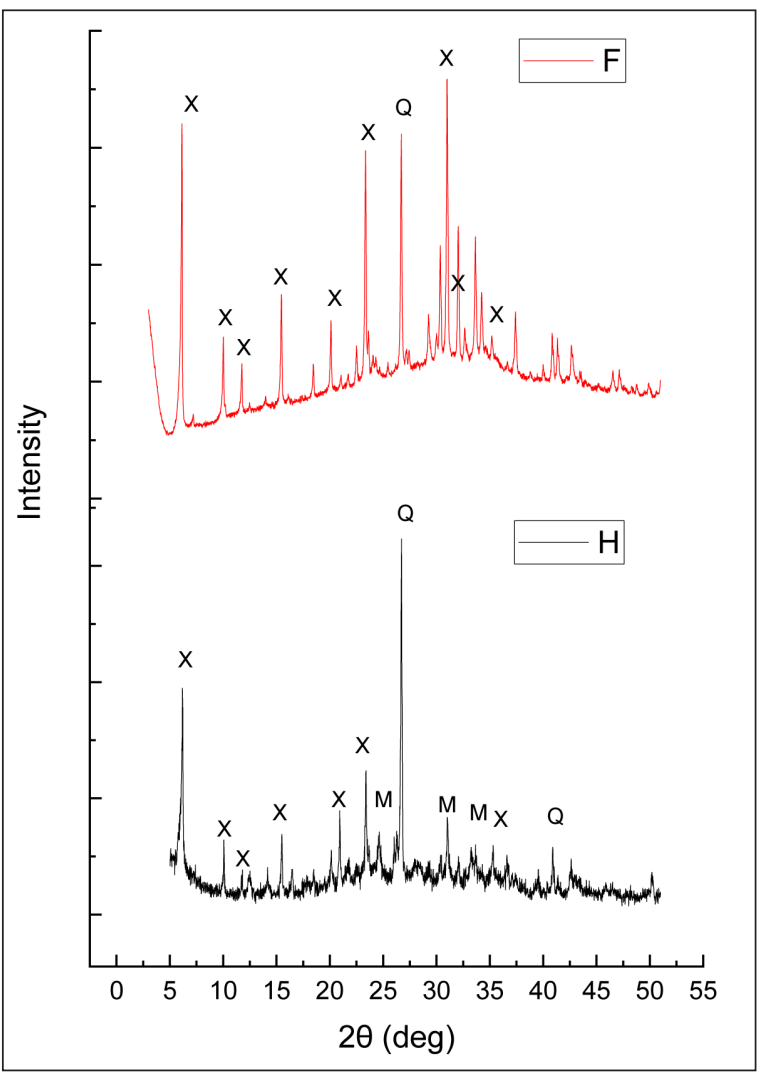

Fig. 5. Diffraction pattern for fusion synthesised material - $F$ and hydrothermally synthesised material - H (X-zeolite X, M-mullite, Q quartz)

\section{Sorption results}

In the following adsorption data (i.e. Fig. 6) there were presented results of sulphur dioxide sorption. For the purpose of description of the data there were selected two models for received data analysis: Freudlich, eq. (1), and Langmuir, eq. (2):

$$
\begin{aligned}
& a=k p^{1 / n}, \\
& a=\frac{a_{m} k p}{1+k p},
\end{aligned}
$$

where: $a$ is adsorption; $p$ is adsorbate pressure; $k$ and $n$ are constants for a given adsorbate and adsorbent at a particular temperature; $a_{m}$ is adsorption value corresponding to monolayer filling.

All sorption data as well as curves obtained with the use of Freudlich and Langmuir models are collected in Fig. 6.

In Table 2 there are presented the calculated parameters for Freudlich and Langmuir isotherm models, as well as coefficients of determination.

\section{DISCUSSION}

\section{Fly ash zeolite synthesis}

It is possible to synthesise zeolites by using fly ash as a substrate. Selection of appropriate parameters allows for the formation of zeolite type X, both in fusion and hydrothermal methods. The conversion rate of fly ash transformation into zeolite is different in both methods. In case of the hydrothermal method, XRD diffraction patterns show pronounced reflections form quartz and mullite, confirming that not all silica and alumina sources

\begin{tabular}{|c|c|c|c|c|c|c|c|c|c|}
\hline \multirow[b]{2}{*}{$\frac{\text { 을 }}{\text { है }}$} & \multicolumn{4}{|c|}{ Freudlich } & \multirow[b]{2}{*}{ 营 } & \multicolumn{4}{|c|}{ Langmuir } \\
\hline & $\begin{array}{l}\text { むัँ } \\
\text { Еัँ }\end{array}$ & \multicolumn{3}{|c|}{ Sorption cycle } & & 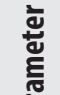 & \multicolumn{3}{|c|}{ Sorption cycle } \\
\hline \multirow{4}{*}{$\mathrm{H}$} & & $\mathbf{I}$ & II & III & \multirow{4}{*}{$\mathrm{H}$} & & I & II & III \\
\hline & $1 / n$ & 0.364 & 0.454 & 0.353 & & $a_{m}$ & 0.880 & 0.445 & 0.447 \\
\hline & $k$ & 0.060 & 0.016 & 0.031 & & $k$ & 0.004 & 0.003 & 0.005 \\
\hline & $\mathrm{R}^{2}$ & 0.996 & 0.986 & 0.992 & & $\mathrm{R}^{2}$ & 0.997 & 0.971 & 0.985 \\
\hline \multirow{4}{*}{$\mathrm{F}$} & & $\mathbf{I}$ & II & III & \multirow{4}{*}{$\mathrm{F}$} & & $\mathbf{I}$ & II & III \\
\hline & $1 / n$ & 0.213 & 0.566 & 0.332 & & $a_{m}$ & 1.835 & 1.187 & 0.925 \\
\hline & $k$ & 0.385 & 0.016 & 0.082 & & $k$ & 0.009 & 0.002 & 0.005 \\
\hline & $\mathrm{R}^{2}$ & 0.968 & 0.973 & 0.976 & & $\mathrm{R}^{2}$ & 0.990 & 0.911 & 0.986 \\
\hline
\end{tabular}

Table 2. Comparison of Freudlich and Langmuir parameters 
F sample sorption results along with the fitting of the theoretical model to the experimental data

(a)

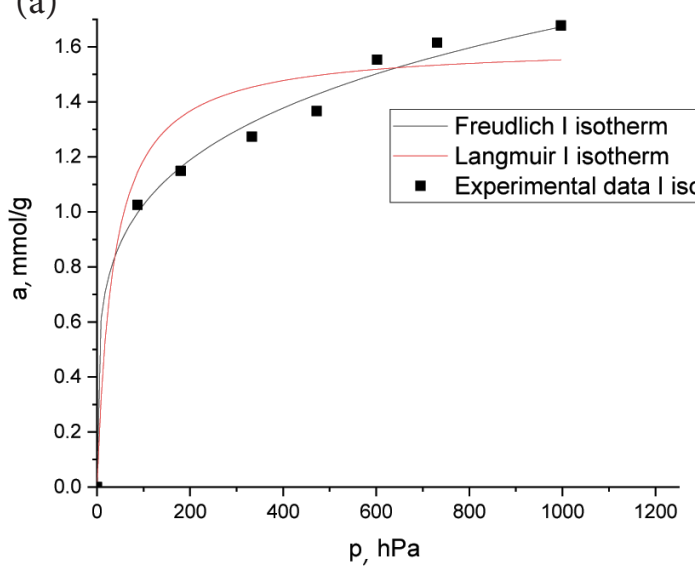

(b)

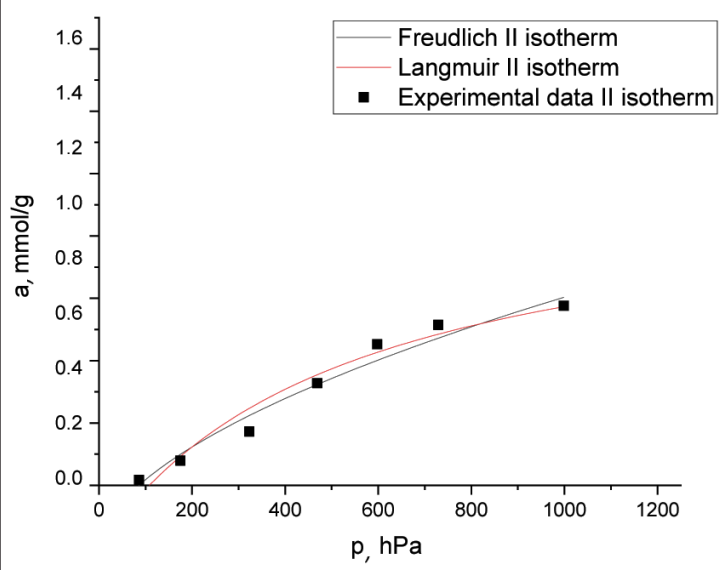

(c)

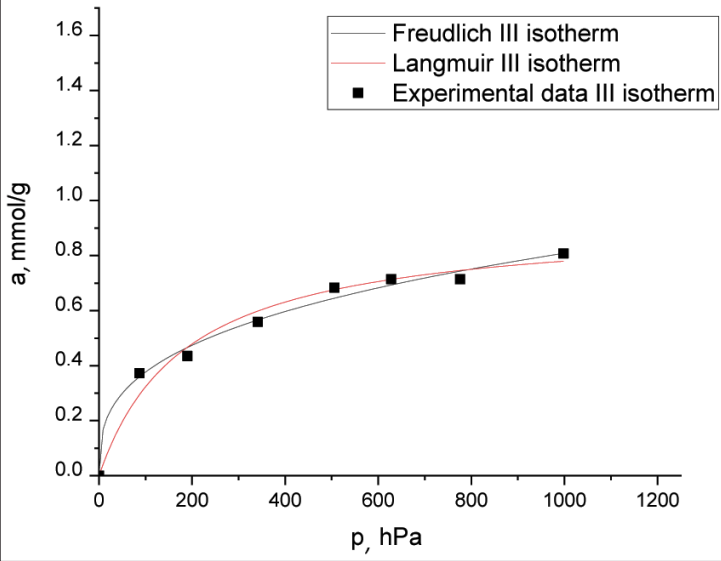

$\mathrm{H}$ sample sorption results along with the fitting of the theoretica model to the experimental data

(d)

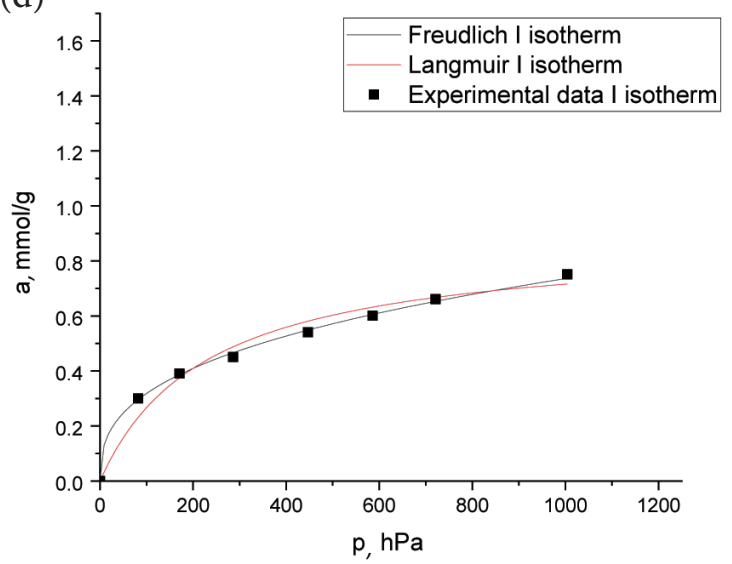

(e)

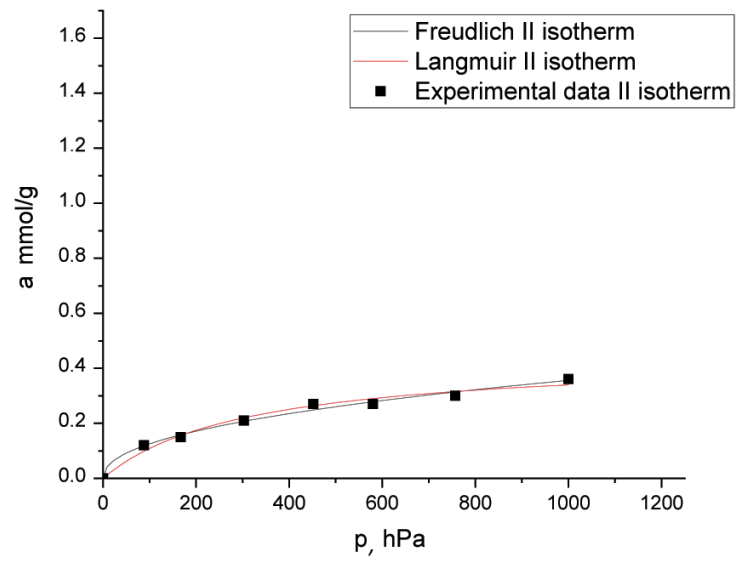

(f)

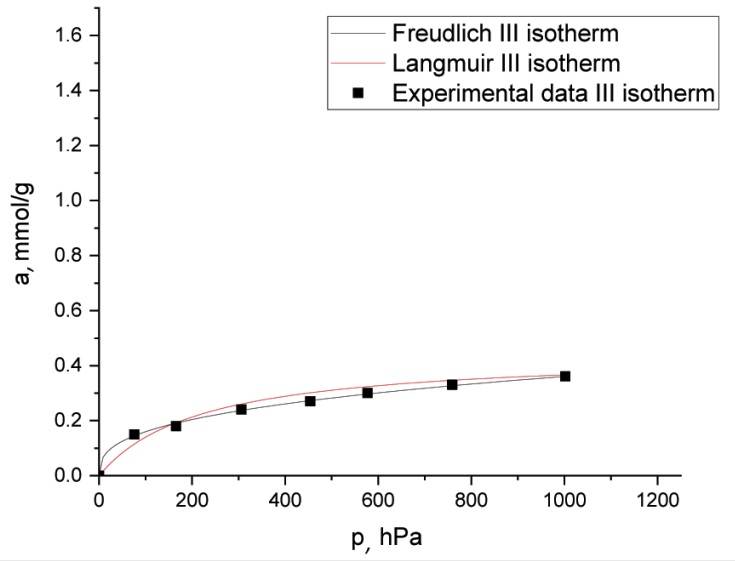

Fig. 6. Comparison of $\mathrm{SO}_{2}$ sorption data: (a) I sorption cycle for $\mathrm{F}$ sample, (b) II sorption cycle for $\mathrm{F}$ sample, (c) III sorption cycle for $\mathrm{F}$ sample, (d) I sorption cycle for $\mathrm{H}$ sample, (e) II sorption cycle for $\mathrm{H}$ sample, (f) III sorption cycle for $\mathrm{H}$ sample

were dissolved and recrystallized in the form of zeolite. In case of the fusion method the presence of other than zeolite phases is not so explicit.

\section{Sorption experiments}

Received fly ash zeolites may be used as sulphur dioxide sorbents. Analysis of experimental data 
allows for the firstly noticing significant differences in adsorbed amounts of sulphur dioxide in case of different synthesis methods. This phenomenon is connected with a different amount of zeolite present in the sample. The fusion synthesis method is presented in literature [8] as the method allowing for the highest degree of conversion of fly ash into zeolite. It is, however, worth noticing that the hydrothermal method is a much more convenient method in case of lower energy consumption required; what's more, it is possible to transform it into semi-industrial, or even industrial scale [9-10]. Based on received data it can be stated that in case of samples synthesised with the use of the fusion method, the sorption capacity is two times higher than in case of the hydrothermal synthesis method. Due to the nature of synthesized materials, up to date there is no method for accurate and absolute determination of zeolite amount present in the sample; therefore, a detailed analysis of correlation between sorption capacity and zeolite amount present in the sample is not possible.

What is noted in case of sorption isotherms experimental data in connection to observation of cyclic sorption is the fact that after the first sorption cycle the sorption capacity is lower for samples synthesised with the use of both methods. What is interesting is that no further decrease is observed after the second cycle. Authors assume that this phenomenon is connected with the nature of synthesised samples. Both syntheses have been performed with the use of $\mathrm{NaOH}$. Due to zeolite structure the process of washing did not result in full removal of non-reacted $\mathrm{NaOH}$. The remaining hydroxide is highly possible to react with sulphur dioxide. This however would take place only in the first cycle.

The performance of sulphur dioxide sorption in three cycles was directed by the will to perform a preliminary test in regeneration possibilities of synthesised materials. Despite the fact that only three cycles were performed, the preliminary observation was made that samples would regenerate, not taking into account decrease after the first cycle described below. The regeneration of this material needs further tests.

The research focused on the analysis of adsorption phenomena needs the application of appropriate theory, as well as models describ- ing the adsorption process. For the purpose of the description of received experimental data there were chosen basic models: Freudlich and Langmuir. In case of Freudlich adsorption isotherm the use of this model may be justified by the fact that experimental points seem even visually to represent the Freudlich isotherm shape. Additionally, Freudlich isotherm is appropriate for the description of microporous, non-homogenous sorbents [2, 11-13]. Langmuir isotherm was selected for the purpose of comparison as one of the most known and widely used adsorption isotherm models. The limitations included in Langmuir theory assumptions suggest that the description of sulphur dioxide sorption on fly ash zeolites may not give well correlated results.

The constant $n$ in the Freundlich equation gives the indication of heterogeneity of the surface adsorption energy, its value of more than 1 should be expected. When $n=1$, the assumption of complete energy homogeneity of the surface can be made [13]. In case of performed analysis the values in all cases are higher than 1, proving information of heterogeneous surface.

Representation of results in a form of graphs and $R^{2}$ values allows to find that the preliminary assumption was correct and analysed experimental data were generally better described by Freudlich isotherm. What was noticed was that in case of the first sorption cycle the $\mathrm{R}^{2}$ coefficient was better for Langmuir, what can be attributed to a different mechanism of sorption which in case of the first cycle was chemisorption.

\section{CONCLUSIONS}

It is possible to synthesise zeolites from fly ashes using fusion and hydrothermal methods. By selection of appropriate synthesis parameters the same type of zeolite - zeolite X may be received in both synthesis methods. Fly ash degree of conversion into zeolite differs accordingly due to the synthesis method used.

The received fly ash zeolites synthesised in both synthesis methods may be used as sulphur dioxide sorbents. The sorption capacity of zeolite $\mathrm{X}$ synthesised by the fusion method presents two times higher values than for samples synthesized by the hydrothermal method, which is 
associated with the quantity of zeolite present in the sample. Sorption capacity decreases after the first cycle, most probably due to chemical bounding of sulphur dioxide with non-reacted sodium hydroxide. In the following cycles no further decrease in sorption capacity is observed, which is a preliminary premise for regeneration properties of the synthesised materials.

\section{ACKNOWLEDGEMENTS}

The authors are grateful to AGH University of Science and Technology (Project 15.11.210.381) for its financial support of this work.

Received 1 February 2018 Accepted 15 March 2018

\section{References}

1. Pajdak A. The effect of structure modification of sodium compounds on the $\mathrm{SO}_{2}$ and $\mathrm{HCl}$ removal efficiency from fumes in the conditions of circulating fluidised bed. Chemical and Biochemical Engineering Quarterly. 2017. Vol. 31. No. 3. P. 261-273.

2. Gruszecka-Kosowska A., Baran P., Wdowin M., Franus W. Waste dolomite powder as an adsorbent of $\mathrm{Cd}, \mathrm{Pb}(\mathrm{II})$, and $\mathrm{Zn}$ from aqueous solutions. Environmental Earth Sciences. 2017. Vol. 76. Iss. 15. Article 521.

3. Rhodes C. J. Properties and applications of zeolites. Science Progress. 2010. Vol. 93. No. 3. P. 223-284.

4. Quero X., Moreno N., Umana J. C., Alastuey A., Hernandez E., Lopez-Soler A., Plana F. Synthesis of zeolites from coal fly ash: an overview. International Journal of Coal Geology. 2002. Vol. 50. Iss. 1-4. P. 413-423.

5. Ríos C. A., Williams C. D., Castellanos O. M. Crystallization of low silica $\mathrm{Na}-\mathrm{A}$ and $\mathrm{Na}-\mathrm{X}$ zeolites from transformation of kaolin and obsidian by alkaline fusion. Ingeniería y Competitividad. 2012. Vol. 14. No. 2. P. 125-137.

6. Thuadaij P., Nuntiya A. Synthesis of Na-x hydrate zeolite from fly ash and amorphous silica from rice husk ash by fusion with caustic soda prior to incubation. International Conference on Chemistry and Chemical Process. 2011. Vol. 10. P. 69-74.

7. Wdowin M., Macherzyński M., Panek R., Górecki J., Franus W. Investigation of the sorption of mercury vapour from exhaust gas by an Ag-X zeolite. Clay Minerals. 2015. Vol. 50. No. 1. P. 31-40.

8. Querol Carceller X., Moreno N., Alastuey A., Juan Mainar R., Andrés Gimeno J. M., López-Soler Á., Ayora C., Medinaceli A., Valero A. Synthesis of high ion exchange zeolites from coal fly ash. Geologica Acta. 2007. Vol. 5. Iss. 1. P. 49-57.

9. Wdowin M., Franus M., Panek R., Badura L., Franus W. The conversion technology of fly ash into zeolites. Clean Technologies and Environmental Policy. 2014. Vol. 16. No. 6. P. 1217-1223.

10. Querol X., Umaña J. C., Plana F., Alastuey A., Medinaceli A., Valero A., Domingo M. J., Garcia-Rojo E. Synthesis of zeolites from fly ash in a pilot plant scale. Examples of potential environmental applications. 1999 International Ash Utilization Symposium, 1999.

11. De Sá A., Abreu A. S., Moura I., Machado A. V. Polymeric materials for metal sorption from hydric resources. Nanotechnology in the Agri-Food Industry. 2017. P. 289-322.

12. Ye C. Z., Ariya P. A. Co-adsorption of gaseous benzene, toluene, ethylbenzene, m-xylene (BTEX) and $\mathrm{SO}_{2}$ on recyclable $\mathrm{Fe}_{3} \mathrm{O}_{4}$ nanoparticles at $0-101 \%$ relative humidities. Journal of Environmental Sciences. 2015. Vol. 31. P. 164-174.

13. Czarna D., Baran P., Kunecki P., Panek R., Żmuda R., Wdowin M. Synthetic zeolites as potential sorbents of mercury from wastewater occurring during wet FGD processes of flue gas. Journal of Cleaner Production. 2018. Vol. 172. P. 2636-2645. 
Natalia Czuma, Katarzyna Zarębska, Paweł Baran, Piotr Gauden

MATEMATINIŲ MODELIŲ NAUDOJIMAS

MODELIUOJANT SIEROS DIOKSIDO

SUGERTIES MEDŽIAGAS, PAGAMINTAS IŠ LAKIŲJŲ PELENŲ

\section{Santrauka}

Iš lakiųjų pelenų pagaminti ceolitai gali tapti patraukli alternatyva natūraliems ir iš grynų cheminių medžiagų pagamintiems ceolitams. Didejantis aplinkosaugos poreikis yra paskata panaudoti atliekas kaip žaliavą mikroporinių, plataus naudojimo medžiagų - ceolitų gamybai. Be to, aplinką tausojantiems veiksmams, kurių imamasi siekiant sumažinti oro taršą, reikia ieškoti naujų būdų, kaip sugaudyti pavojingus oro teršalus. Ceolitai gali būti naudojami kaip oro teršalų sorben- tai. Šiame straipsnyje pateikti sieros dioksido, vieno iš dūmų komponento, sorbcijos eksperimentų rezultatai. Kaip sugèriklis buvo naudotas ceolitas, sintezuotas iš lakiųjų pelenų, iš pasirinktos jègainès Lenkijoje. Tyrimo tikslais buvo parinkti lakiųjų pelenų ceolito mèginius ir sintetinti juos naudojant įvairius metodus. Parametrai buvo parinkti taip, kad būtų gauta vieno tipo ceolito medžiaga. Gautiems rezultatams apibūdinti buvo naudojamas matematinis modelis. Remiantis atliktais eksperimentais nustatyta, kad sintezès medžiagos gali būti naudojamos kaip sieros dioksido sorbentas. Nustatyta, kad sorbcijos talpa yra glaudžiai susijusi su ceolito sintezès metodu. Nors buvo gautas tas pats ceolito tipas, mèginiai parodè diferencijuotas gaudymo vertes dèl skirtingų lakiųjų pelenų perskaičiavimo koeficientų i ceolito medžiagas.

Raktažodžiai: lakieji pelenai, ceolitas, sugertis, modeliavimas 